\title{
The Relationship Between Immunoglobulin E Serum Levels And Age-Related Cataract
}

\author{
Meidina Rahmah ${ }^{1 *}$, Alie Solahuddin ${ }^{1 *}$ \\ ${ }^{1}$ Department of Ophthalmology, Faculty of Medicine, Universitas Sriwijaya, Indonesia \\ *Correspondence author email : meidinarahmah@gmail.com
}

\begin{abstract}
Background: To determine the relationship of serum IgE levels and age-related cataract at the Special Eye Hospital in Palembang.

Methods: An observational study with cross-sectional design study was undertaken in October 2018 to May 2019 at the Special Eye Hospital in Palembang. There were 86 patients who met the inclusion and exclusion criteria. The independent variable in this study is the level of serum immunoglobulin $\mathrm{E}$ and the dependent variable is senile cataract. The data analysis has been done with diagnostic research by SPSS version 20.0 (SPSS, Inc Chicago, Illinois).

Results: Thirty five people suffered from senile cataracts and fifty one people did not suffer from cataracts. The mean IgE level in senile cataract patients was $5.129 \pm 1.588 \mathrm{ng} / \mathrm{mL}$ while in patients without cataracts it was $5.001 \pm 1.564 \mathrm{ng} / \mathrm{mL}$. There was no difference in IgE levels between senile cataract patients and patients without cataracts $(\mathrm{p}=0.891)$. With statistical analysis using the ROC curve it was found that the IgE concentration cut off point was $5.046 \mathrm{ng} / \mathrm{mL}$. There were $54.3 \%$ of senile cataract patients and $51 \%$ of patients without cataracts who had $\operatorname{IgE}$ levels $>5.046 \mathrm{ng} / \mathrm{mL}$. Patients with IgE levels > 5.046 had an almost equal risk of senile cataracts compared to patients with IgE levels <5.046 ( $\mathrm{PR}=1.142(\mathrm{CI} 95 \% 0.482-2.705 ; \mathrm{p}=0.935)$.

Conclusion: There is no significant relationship between IgE levels and the incidence of senile cataracts.
\end{abstract}

Keywords: Senile cataract, Immunoglobulin E, Cross sectional 


\section{SRIWIJAYA JOURNALOF OPHTHALMOLOGY}

Sप्रP

\section{Introduction}

Cataract is a turbidity that occurs in the lens, where the lens is a clear structure located behind the iris and in front of the vitreous. ${ }^{1}$ Senile cataract is a clouding of the lens that occurs at more than 40 years of age. ${ }^{2}$ Cataract is the most common cause of loss of vision in the world. According to the World Health Organization (WHO), cataracts cause vision problems by $33 \%$ and blindness by $51 \% .^{3}$

Lens turbidity occurs due to protein aggregation that appears without a definitive cause. Some risk factors are considered related to the occurrence of lens turbidity, including: family history, diabetes, hypertension, smoking, and sun exposure. The composition of the cloudy lens is unknown but changes in the structure of crystalline (a protein that maintains lens transparency) are considered to be involved and are accelerated in the presence of oxidative stress. ${ }^{4}$

Immunoglobulin $\mathrm{E}(\mathrm{IgE})$ is an antibody that binds to the Fc receptor which is most found on the surface of mast cells and has a role in the response to allergens. ${ }^{5}$ The binding between $\operatorname{IgE}$ and $\mathrm{Fc}$ receptors activates degranulated mast cells, followed by the release of inflammatory mediators, such as cytokines, chemokines, histamine, proteoglycans, and mast cell proteases.

These mediators induce hypersensitivity reactions. ${ }^{6}$ Because the immune response mediated by $\operatorname{IgE}$ is a trigger for systemic inflammation that produces oxidative stress, there is a suspicion that serum IgE levels are related to the process of cataract formation. This research will prove relationship between immunoglobulin E levels and senile cataracts.

\section{Methods}

An observational study with cross-sectional design study was undertaken in October 2018 to May 2019 at the Special Eye Hospital in Palembang. There were 86 patients who met the inclusion and exclusion criteria. The protocol has been approved of Ethics Committee, Faculty of Medicine Sriwijaya University. Sampling in this study was carried out simple random based on gender and stratification based on age. The diagnosis of senile or non-senile cataracts is made through history taking and routine ophthalmological examinations ranging from visual examination with Snellen Chart, intraocular pressure examination (IOP) with Schiotz tonometer, anterior segment eye examination with biomicroscopic slit lamp, and posterior segment eye examination with direct fundoscopic examination. Examination of Imunoglobulin $\mathrm{E}$ by taking 


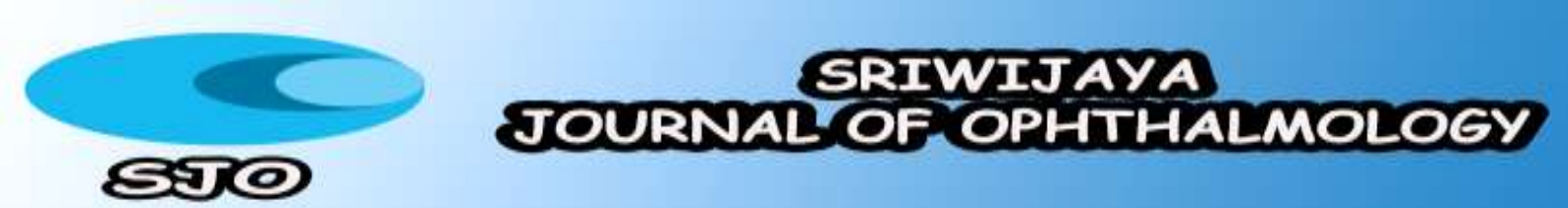

blood samples as much as $2.5 \mathrm{ml}$ and examined at the Biomolecular Laboratory, Faculty of Medicine Sriwijaya University. The frequency and distribution of patient data are described in univariate table and graph, and the relationship between immunoglobulin E levels and senile cataracts was tested using the Chi Square test. Chi Square Test was determined with an $\alpha$ value of 0.05. Data analysis was performed using SPSS version 20.0

\section{Result}

In the period October 2018 to April 2019 there are 86 patients who meet the criteria of inclusion and exclusion. Thirty five people suffered from senile cataracts and fifty one people did not suffer from cataracts.

Table 1 summarize that based on age, the average age of senile cataract patients was 64.00 \pm 10.36 years with the most age group being 61-70 years (40\%) while the average age of respondents without cataracts was $48.82 \pm 5.21$ years with the most age groups being 40 -50 years (70.6\%). In senile cataract patients, the male sex (51.4\%) and female (48.6\%) were almost the same, while in the patients without cataract the majority were male (64.7\%). 

JOURNALOFOPHTHALMOLOGY

Table 1: Characteristics demographics of research subject

\begin{tabular}{lccc}
\multirow{2}{*}{ Characteristics } & \multicolumn{2}{c}{ Senile Cataract } & \multirow{2}{*}{ p value } \\
\cline { 2 - 3 } Age (years) & $64,00 \pm 10,36$ & $48,82 \pm 5,21$ & $0,000^{\mathrm{a}}$ \\
& $64(45-89)$ & $48(41-61)$ & \\
\hline Age, n (\%) & & & \\
$40-50$ & $4(11,4)$ & $36(70,6)$ & \\
$51-69$ & $10(28,6)$ & $14(27,5)$ & $0,000^{\mathrm{b}}$ \\
$61-70$ & $14(40,0)$ & $1(2,0)$ & \\
$>70$ & $7(20,0)$ & $0(0)$ & \\
& & & \\
\hline Sex, n (\%) & & & $0,314^{\mathrm{c}}$ \\
Male & $18(51,4)$ & $33(64,7)$ & \\
Female & $17(48,6)$ & $18(35,3)$ & \\
\hline Education & & & \\
Elementary school & $20(57,1)$ & $20(57,1)$ & \\
Junior high school & $5(14,3)$ & $5(14,3)$ & \\
Senior high school & $4(11,4)$ & $4(11,4)$ & \\
Bachelor degree & $6(17,1)$ & $6(17,1)$ & \\
\hline Occupation & & & \\
Unemployment & $4(11,4)$ & $0(0)$ & \\
Housewives & $12(34,3)$ & $11(21,6)$ & \\
Government & $3(8,6)$ & $10(19,6)$ & \\
employees & $2(5,7)$ & $20(39,2)$ & $0,000^{\mathrm{b}}$ \\
Entrepreneur & & & \\
Pensioners & $9(25,7)$ & $1(2,0)$ & \\
Laborers & $2(5,7)$ & $6(11,8)$ & \\
Traders & $1(2,9)$ & $2(3,9)$ & \\
Farmers & $2(5,7)$ & $1(2,0)$ & \\
\hline & & & \\
\hline
\end{tabular}

${ }^{\mathrm{a}}$ Mann Whitney, $p=0,05,{ }^{\mathrm{b}}$ Pearson Chi Square, $\mathrm{p}=0,05,{ }^{\mathrm{c}}$ Chi Square, $\mathrm{p}=0$,

The majority of primary school cataract patient education is primary school $(57.1 \%)$ while the majority of patients without cataract have college education $(39.2 \%)$. The most occupations of senile cataract patients were housewives $(34.3 \%)$ while the most occupational patients without cataracts were private $(39.2 \%)$.

With statistical tests the results showed there is a difference in age $(p=0,000)$ education $(p=0,019)$ and occupation $(p=0,000)$ between senile cataract patients and patients without cataracts. In addition, the results obtained no gender differences $(p=0.314)$ between senile cataract patients and patients without cataracts.

The most cataract morphology on the right is the nucleus type as many as 23 people $(65.7 \%)$, followed by mixed types as many as 8 people $(22.9 \%)$ and 1 person each posterior and cortical subcapsular types. In the left eye the cataract morphology also found that most were nuclear as many as 19 people (54.3\%) and mixed types as many as 9 people $(25.7 \%)$. Data on the distribution of cataract categories can be seen in table 2. 
Table 2: Cataract characteristics

\begin{tabular}{lcc}
\hline \multicolumn{1}{c}{ Category } & Right Eyes & Left Eye \\
\hline - Nuclear & $23(65,7)$ & $19(54,3)$ \\
- Corticalis & $1(2,9)$ & $0(0)$ \\
- Posterior & $1(2,9)$ & $0(0)$ \\
subcapsularis & & \\
- Mixed & $8(22,9)$ & $9(25,7)$ \\
- Pseudofakia & $2(5,7)$ & $7(20)$ \\
\hline
\end{tabular}

Table 3 shows the results that there were no differences in IgE levels between senile cataract patients and patients without cataracts $(\mathrm{p}=0.891)$. IgE levels in senile cataract patients were 5,129 $\pm 1,588 \mathrm{ng} / \mathrm{mL}$ with a range of 2,899 - 9,866 ng / $\mathrm{mL}$ whereas in patients without cataracts the mean $\mathrm{IgE}$ levels were 5,001 $\pm 1,564 \mathrm{ng} / \mathrm{mL}$ with a range of 2,285 $7,953 \mathrm{ng} / \mathrm{mL}$.

Table 3: Level of Serum Immunoglobulin E

\begin{tabular}{|c|c|c|c|}
\hline \multirow[t]{2}{*}{ Characteristics } & \multicolumn{2}{|c|}{ Senile Cataract } & \multirow[t]{2}{*}{ p value } \\
\hline & Yes & No & \\
\hline $\begin{array}{c}\text { Imunoglobulin E } \\
- \text { Mean } \pm \text { SD } \\
- \text { Min-max }\end{array}$ & $\begin{array}{c}5,129 \pm 1,588 \\
2,899-9,866\end{array}$ & $\begin{array}{l}5,001 \pm 1,564 \\
2,285-7,953\end{array}$ & 0,891 \\
\hline
\end{tabular}

\section{Uji Mann Whitney, $p=0,05$}

Figure 1 is the intersection curve for IgE levels. From this figure, the best value for sensitivity and specificity is 5. 046. Nineteen of thirtyfive senile cataract patients (54.3\%) had IgE levels $>5.046$ while those without cataracts totaling 26 of 51 patients (51.0\%) also had IgE levels> 5,046. With the Chi Square test it was concluded that there was no significant relationship between IgE levels and the incidence of senile cataracts, patients with IgE levels $>5.046$ had an almost equal risk of senile cataracts compared to patients with IgE levels < $5.046(\mathrm{PR}=1.142(\mathrm{CI} 95 \% 0.482-2.705 ; \mathrm{p}=0.935)$. 


\section{JOURNALOFOPHTHALMOLOGY}

\section{SSO}

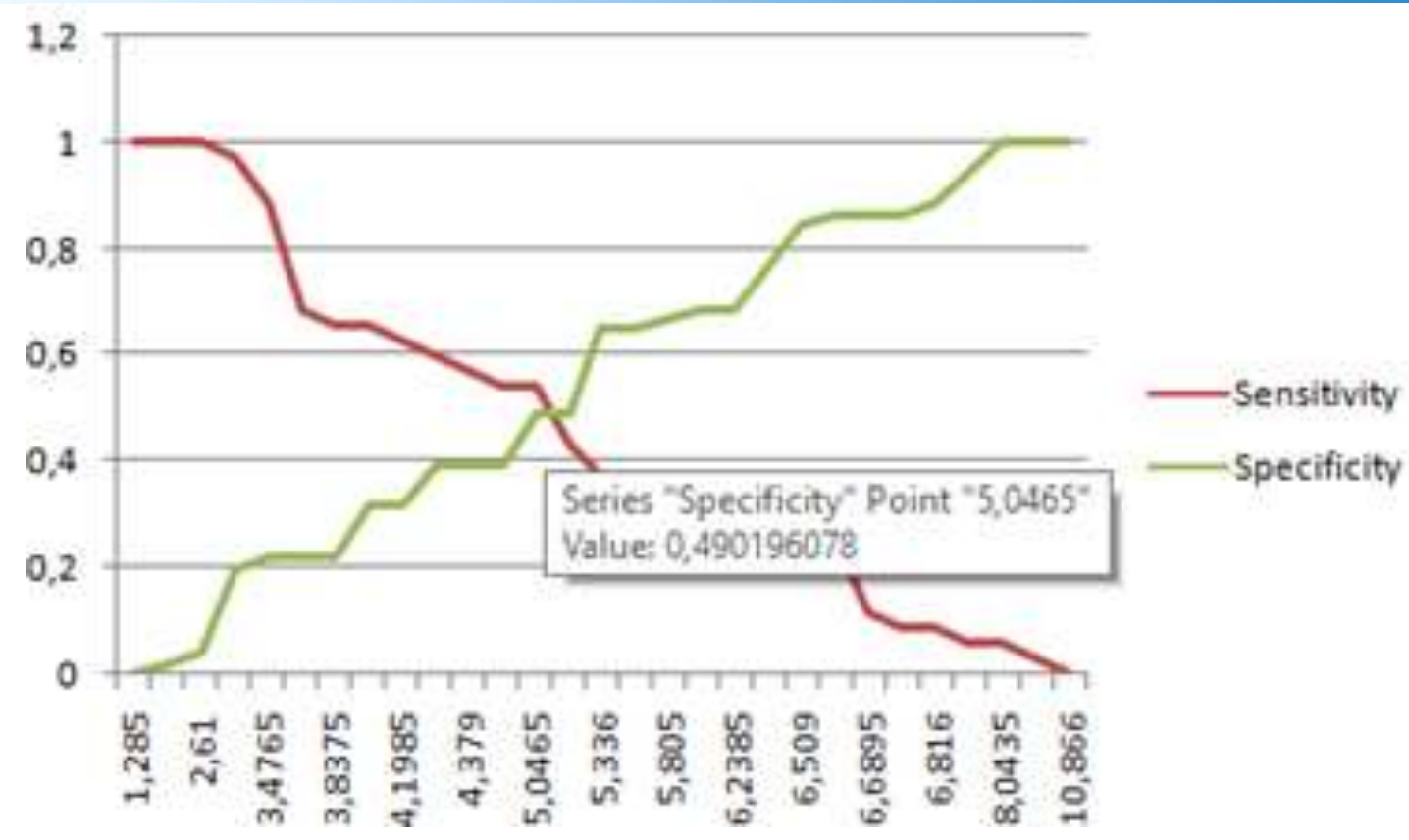

Figure 1. Intersection curve for IgE levels

Table 4: The Relationship between Immunoglobulin E Levels and the Occurrence of Senile Cataracts.

\begin{tabular}{|c|c|c|c|c|}
\hline \multirow[t]{2}{*}{ Characteristics } & \multicolumn{2}{|c|}{ Senile Cataract } & \multirow{2}{*}{$\begin{array}{c}\text { PR } \\
(\mathrm{CI} 195 \%)\end{array}$} & \multirow[t]{2}{*}{ p value } \\
\hline & Yes & No & & \\
\hline \multicolumn{5}{|l|}{ Imunoglobulin E } \\
\hline$->5.046$ & 19 & 26 & \multirow[t]{3}{*}{, 143} & \multirow[t]{3}{*}{.935} \\
\hline$-\leq 5.046$ & 16 & 25 & & \\
\hline Total & 5 & 51 & & \\
\hline
\end{tabular}

\section{Discussion}

In this study, there were a total of 86 research subjects, consisting of 35 people suffering from senile cataracts and 51 others without cataracts. These results indicate that the prevalence of senile cataracts in this study was $40.7 \%$. This is not much different from the study of Yoo et al in South Korea who get a senile cataract prevalence of $34 \% .^{7}$

In the group of subjects with senile cataracts the mean age of the patients was 64.00 \pm 10.36 years with the most age group being $61-70$ years $(40 \%)$. The prevalence of senile 


\section{SRIWIJAYA \\ JOURNALOF OPHTHALMOLOGY}

धत्र०

cataracts will increase rapidly with age. Age is an important risk factor for cataracts. As the lens protein (crystalline) grows, it changes due to chemical modification and aggregation so that its molecular weight increases. Protein aggregation reduces transparency. Chemical modification of the lens nucleus protein also causes progressive pigmentation, the lens turns yellow or brownish. ${ }^{8}$ The modification of the crystalline lens can also be aggravated by the presence of oxidative stress which increases with age. ${ }^{9,10}$

In this study, the proportion of senile cataract sufferers of male sex is the same as female sex with a ratio of 1: 1 . The results of this study are not much different from a study in Australia in 2008 conducted by Kanthan et al who stated that the sexes of men and women have the same risk in the incidence of senile cataracts.This is different from the findings in other studies.11 Zhu RR et al stated that the prevalence of senile cataracts was higher in women than in men. The difference in these results was possible due to an increase in women's empowerment, a high level of awareness for treatment, or the result of hormonal changes associated with menopause. ${ }^{12}$

In this study, the most common type of cataract morphology in both the right and left eye was nuclear type as much as $65.7 \%$ and $54.3 \%$. This is consistent with the results of the study of Glynn et al in the United States which concluded that nuclear cataracts are the most common cataract morphology found in senile cataracts.13 Age-Related Eye Disease Study (AREDS) shows that increasing age is significantly associated with the incidence of nuclear cataracts. $^{14}$

With statistical analysis using the ROC curve, the cut-off point for immunoglobulin E based on a cataract diagnosis was $5.046 \mathrm{ng} / \mathrm{mL}$. In this study $54.3 \%$ of senile cataract patients were found and $51 \%$ of patients without cataracts who had $\operatorname{IgE}$ levels> 5,046 ng / $\mathrm{mL}$. With the Chi Square test, it was concluded that there was no significant relationship between immunoglobulin $\mathrm{E}$ levels and the incidence of senile cataracts (PR $=1.142$ (CI95\% 0.482-2.705; $\mathrm{p}=0.935)$ ). This is in contrast to the results of research by Yoo et al in South Korea which concluded that elevated levels of immunoglobulin E are associated with the incidence of senile cataracts. ${ }^{7}$

A difference in results might occur due to the small number of samples in this study. In addition there are differences in general characteristics of the sample in the two groups 


\section{JOURNAL OF OPHTHALMOLOGY}

हज्ञ०

may be a bias of this study. For this reason, further research is needed with a larger number of samples and similar characteristics of the samples.

\section{Conclusion}

There is no significant relationship between $\operatorname{IgE}$ levels and the incidence of senile cataracts, there were no differences in IgE levels between senile cataract patients and patients without cataracts.

\section{Acknowledgment}

We would like to thank Dr. Debby Handayati, M.Kes, for assistance the publication of this paper.

\section{References}

1. Asbell PA, et al. Age-related cataract. Lancet. 2005; 365: 599-609

2. Hemminki Kari, et al. The Incidence of Senile Cataract and Glaucoma is Increased in Patients with Plasma Cell Dyscrasias: Etiologic Implications. Sci Rep. 2016; 6: 28500.

3. Global data on visual impairments 2010. World Health Organization

4. Hejtmancik JF, Kantorow Marc. Molecular genetics of age-related cataract. Exp Eye Res. 2004 Jul; 79(1): 3-9.

5. Conner ER, Saini SS. The immunoglobulin E receptor: expression and regulation. Curr Allergy Asthma Rep. 2005; 5: 191-19

6. Lippi G, Cervellin G, Sanchis-Gomar F. Immunoglobulin E (IgE) and ischemic heart disease. Which came first, the chicken or the egg? Ann Med. 2014; 46: 456-463

7. Yoo TK, Kim SW, Seo KY. Age Related Cataract Is Associated with Elevated Serum Immunoglobulin E Levels in the South Korean Population: A CrossSectional Study. PLoS ONE. 2016 (11): e0166331

8. American Academy of Opthalmology. Lens and cataract. San Fransisco: AAO Publisher. 2014

9. Vinson JA. Oxidative stress in cataracts. Pathophysiol Off J Int Soc Pathophysiol ISP. 


\section{JOURNALOF OPHTHALMOLOGY}

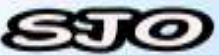

2006; 13: 151-162

10. Sihota R, Tandan R. Parson's disease of the eye. Indian: Elsevier. 2007

11. Kanthan GL, Wang JJ, Rochtchina E, et al. Ten-yeat incidence of age-related cataract and cataract surgery in an older Australian population. Ophthalmology. 2008;115(5): 808-814

12. Zhu RR, Shi J, Yang M,Guan HJ. Prevalences and causes of vision impairment in elderly Chinese: a socioeconomic perspective of a comparative report nested in Jiangsu Eye Study. Int J Ophthalmol 2016; 9:1051-1056

13. Glynn RJ, Rosner, Christen WG. Evaluation of risk factors for cataract types in a competing risks framework. Ophthalmic Epidemiol. 2009 (16); 98- 106

14. Chang JR, Koo E, Agron E et al. Risk factors associated with incident cataracts and cataract surgery in the Age-Related Eye Disease Study (AREDS): AREDS Report Number 32. Ophthalmology. 2011. 118: 2113-2119 


\section{जड्ग}

